\title{
Combined effects of nutrients and small-scale turbulence in a microcosm experiment. I. Dynamics and size distribution of osmotrophic plankton
}

\author{
Laura Arin ${ }^{1, *}$, Cèlia Marrasé ${ }^{1}$, Marie Maar ${ }^{2}$, Francesc Peters $^{1}$, \\ Maria-Montserrat Sala ${ }^{1}$, Miquel Alcaraz ${ }^{1}$ \\ ${ }^{1}$ Institut de Ciències del Mar (CMIMA-CSIC), Passeig Marítim de la Barceloneta 37-49, 08003 Barcelona, Spain \\ ${ }^{2}$ National Environmental Research Institute, Frederiksborgvej 399, 4000 Roskilde, Denmark
}

\begin{abstract}
The response of phytoplankton and bacteria dynamics to turbulence and nutrient availability interactions was studied in natural coastal waters enclosed in $15 \mathrm{l}$ microcosms. The effect of turbulence was examined under 3 different nutrient-induced conditions: nitrogen surplus $(\mathrm{N}$, with initial addition of an excess of nitrogen, N:P ratio $=160$ ), nitrogen:phosphorus ratio balanced (NP, with initial addition of nitrogen and phosphorus as Redfield ratio, N:P ratio $=16)$ and control $(C$, no nutrient addition). Turbulence $\left(\varepsilon=0.055 \mathrm{~cm}^{2} \mathrm{~s}^{-3}\right)$ was generated by vertically oscillating grids. The experiment lasted for $8 \mathrm{~d}$ and samples were generally taken daily for nutrient and plankton measurements. Turbulence increased the relative importance of phytoplankton to bacteria when nutrients were added, while in the control the effect of turbulence was negligible. Turbulence also influenced the species' composition and the size distribution of the phytoplankton community. The relative contribution of diatoms to total phytoplankton biomass and the average cell size were higher under turbulence, particularly in $\mathrm{N}$ and NP treatments. The results of these experiments indicate the importance of considering the hydrodynamic conditions in studies addressing competition for nutrients among different osmotrophic organisms in plankton communities.
\end{abstract}

KEY WORDS: Small-scale turbulence $\cdot$ Phytoplankton:bacteria relationship $\cdot$ Phytoplankton size distribution $\cdot$ Phytoplankton composition $\cdot$ Microcosms

Resale or republication not permitted without written consent of the publisher

\section{INTRODUCTION}

In aquatic systems, an osmotrophic cell is said to be diffusion-limited when the uptake rate of the limiting nutrient is faster than the diffusive transport across the boundary layer surrounding the cell (Karp-Boss et al. 1996). Small-scale turbulence (including laminar shear) should theoretically disrupt this layer and thus increase the advective transport of nutrients into the cell. This phenomenon is especially important for nonmotile planktonic cells, which need the movement of water to enhance their nutrient uptake. The increase in

*E-mail: larin@icm.csic.es the nutrient flux into the cells due to small-scale turbulence varies from negligible to significant as cell size increases (Karp-Boss et al. 1996). Karp-Boss and coworkers concluded that small-scale turbulence is only significant for cells $>60 \mu \mathrm{m}$, while small cells should not be directly affected. Some properties of the organisms, such as chain formation in diatoms, could be a mechanism to enhance nutrient uptake due to turbulence when their length approaches the Kolmogorov scale (Karp-Boss et al. 1996, Pahlow et al. 1997, KarpBoss \& Jumars 1998) which is the smallest scale of eddy motion.

In a natural plankton community, both bacteria and phytoplankton compete for limiting nutrients. As mentioned above, small-scale turbulence has been pre- 
dicted to have little effect on the nutrient flux to small planktonic organisms, such as bacteria and small phytoplankton, but could favour large cells in the competition for nutrients. Also, turbulence could select particular life-forms within the phytoplankton community. Frequently, diatoms dominate in turbulent and nutrient-rich waters, while dinoflagellates dominate in calm and nutrient-poor waters. Margalef (1978) suggested that this trend could be due to the different capability of movement of these organisms. In turbulent environments, non-motile and fast-growing life forms could be favoured as large-scale turbulence reduces sedimentation losses out of the photic zone, while dinoflagellates could take advantage in calm waters by increasing nutrient flux through swimming and migratory behaviour. In addition, dinoflagellates seem to be the most sensitive organisms to turbulence (Thomas \& Gibson 1990, Estrada \& Berdalet 1998). Changes in hydrodynamic conditions can affect cell processes like cell division (Berdalet 1992, Thomas et al. 1995), nutrient uptake (Karp-Boss et al. 1996) or swimming motion (Karp-Boss et al. 2000).

Few experimental studies have dealt with the effect of fluid motion on osmotrophic organisms (Pasciak \& Gavis 1975, Canelli \& Fuhs 1976, Savidge 1981, Thomas \& Gibson 1990, Berdalet 1992, Thomas et al. 1995, Köhler 1997). Even fewer have been done with natural plankton communities confined in enclosures (Oviatt 1981, Estrada et al. 1987, 1988, Peters et al. 1998, Petersen et al. 1998, Svensen et al. 2001). Most of those studies show that the extent of turbulence effects on phytoplankton dynamics depends on the initial conditions and nutrient inputs, but none of them reported the relative importance of bacteria versus phytoplankton during the experiment.

As changes in nutrient flux to cells induced by turbulence depend on cell size, we hypothesise that: (1) turbulence increases the relative importance of phytoplankton biomass with respect to bacterial biomass; (2) phytoplankton size distribution is affected by turbulence; and (3) the relative contribution of diatoms to phytoplankton biomass increases with turbulence. To test these hypotheses, we enclosed coastal water from the NW Mediterranean Sea and added nutrients in order to achieve different initial N:P ratios, and then incubated them under still and turbulent conditions. We also expect that the response of plankton to turbulence will be reflected in the organic matter stoichiometry. Data on organic matter quality in relation to the degree of heterotrophy is reported elsewhere (Maar et al. 2002 this issue).

\section{MATERIALS AND METHODS}

Experimental set-up. Surface water from the Catalan coast (Masnou, NW Mediterranean, ca. 1 km offshore) was enclosed in twelve $15 \mathrm{l}$ cylindrical plexiglass containers $(24 \mathrm{~cm}$ inner diameter and $34.5 \mathrm{~cm}$ depth) on March 25, 1998. The water had previously been filtered through a $150 \mu \mathrm{m}$ mesh net in order to remove the larger zooplankton. The experiment was performed in an environmental chamber at $15 \pm 1^{\circ} \mathrm{C}$ under a 12:12 h light:dark cycle and a light irradiance of $225 \mu \mathrm{mol}$ photons $\mathrm{m}^{-2} \mathrm{~s}^{-1}$.

Six of the 12 containers were subjected to turbulence (see below), and the remainder were left under still conditions. Within each group of containers, 2 were left as controls with no nutrient addition (C) and 4 received nitrogen and phosphorus in different proportions. Of these 4, 2 were enriched with a nitrogen-surplus addition $(\mathrm{N})$ and 2 were enriched following the Redfield ratio (NP) (see Table 1). In the $\mathrm{N}$ and NP containers, metals and silicate were also added. The metal solution was added in the same proportion to nitrate as in the f/2 medium (Guillard 1975). All additions were done at the beginning of the experiment.

Small-scale turbulence was generated by vertically oscillating stainless steel grids coated with non-toxic plastic, with a mesh size of $0.6 \mathrm{~cm}$ and bar thickness of $0.35 \mathrm{~cm}$ (Peters et al. 2002). The grid moved down to $1 \mathrm{~cm}$ from the bottom. Stroke length was $20 \mathrm{~cm}$ and oscillation frequency was set to $3.7 \mathrm{rpm}$. Turbulence intensity was calculated from these parameters according to Peters \& Gross (1994) giving an estimation of $0.055 \mathrm{~cm}^{2} \mathrm{~s}^{-3}$. This value is within the range of turbulence intensities in coastal areas (Kiørboe \& Saiz 1995). We also estimated turbulence intensity in the upper

Table 1. Nutrient concentration $(\mu \mathrm{M})$ and N:P ratio in the initial water, and nutrient addition in the 6 (with replicate) different experimental conditions. A and B are replicates, letter combinations explain experimental conditions, e.g. SCA: still control replicate A

\begin{tabular}{|c|c|c|c|c|c|c|c|c|}
\hline Experimental conditons & Still (S) & Turbulent $(\mathrm{T})$ & $\mathrm{PO}_{4}$ & $\mathrm{NH}_{4}$ & $\mathrm{NO}_{2}$ & $\mathrm{NO}_{3}$ & $\mathrm{SiO}_{3}$ & $\mathrm{~N}: \mathrm{P}$ \\
\hline Initial water & & & 0.05 & 0.50 & 0.07 & 0.4 & 0.75 & 19.4 \\
\hline Control (C) & SCA, SCB & TCA, TCB & - & - & - & - & - & 19.4 \\
\hline N-surplus (N) & SNA, SNB & TNA, TNB & 0.1 & - & - & 16 & 30 & 160 \\
\hline Redfield ratio (NP) & SNPA, SNPB & TNPA, TNPB & 1.0 & - & - & 16 & 30 & 16 \\
\hline
\end{tabular}


meters of the NW Mediterranean coastal zone from wind speed data following MacKenzie \& Leggett (1993). Yearly averages fluctuate around $0.007 \mathrm{~cm}^{2} \mathrm{~s}^{-3}$. It is not uncommon to have events with average intensities of the order of $0.01 \mathrm{~cm}^{2} \mathrm{~s}^{-3}$ lasting for $4 \mathrm{~d}$ or more.

When the volume of water decreased due to sampling, the stroke length was corrected to maintain the same energy dissipation rate. The final volume of the containers at the end of the experiment was approximately 51 .

The grids inside the turbulent containers increase the surface:volume ratio. To test for their possible effect on plankton, we set up a trial experiment with natural water and nutrient additions as in the real experiment. Two microcosms were left still without a grid, 2 had moving grids to reproduce the turbulence level $\left(0.055 \mathrm{~cm}^{2} \mathrm{~s}^{-3}\right)$ and 4 microcosms were left still but with grids hanging in the middle of the containers. Changes in phytoplankton biomass were followed over $6 \mathrm{~d}$. An analysis of covariance using the sampling times as covariate showed no statistical difference in chlorophyll a (chl a) concentrations between the still containers with and without grids. On the other hand, turbulence produced higher concentrations of chl a with respect to still containers ( $p<0.001$ ). Thus, the mere presence of grids inside the containers has no effect on plankton dynamics, at least as reflected by chl a concentrations.

Parameters measured. Changes in the measured parameters were monitored over $8 \mathrm{~d}$. Samples for nutrients, total and fractionated chl a, flow cytometry measurements (bacteria, picoeukaryotes, and cells in the genera Synechococcus and Prochlorococcugenera) and autotrophic flagellate counts were, for the most part, taken daily. Samples for coccolithophorid, dinoflagellate and diatom counts were taken on Days 0,4 and 8 .

On Day 8, one replicate of the turbulent N-surplus (TN) and turbulent Redfield ratio (TNP) containers was sampled because the other replicate was left for another experiment. Further, after taking the routine samples at Day 8, each microcosm was strongly mixed until total resuspension of the settled material was achieved. Samples for chl a and bacteria were taken after resuspension. Differences in concentration before and after resuspension were used as an estimation of sedimented phytoplankton and bacterial biomass.

Data were analysed statistically with the analysis of covariance (ANCOVA) using the sampling times as a covariate. The data for time $0(t=0)$ was not considered as treatments had no time to affect the different variables. Statistical significance of a particular treatment was considered when $\mathrm{p} \leq 0.05$.

Nutrients and chl a determinations. Concentration of nitrate, nitrite, ammonia, phosphate and silicate were determined by means of an Alliance Evolution II autoanalyzer, using the methods of Grasshoff et al. (1983) with minor modifications.

Total and fractionated chl a were estimated fluorometrically (Yentsch \& Menzel 1963). For total chl $a_{\text {, }}$ $20 \mathrm{ml}$ samples were filtered through Whatman GF/F filters. For the $>10 \mu \mathrm{m}$ fraction, $40 \mathrm{ml}$ samples were filtered through $10 \mu \mathrm{m}$ pore size polycarbonate filters. To extract chl $a$, all the filters were ground in $90 \%$ acetone and left in the dark at room temperature for at least $2 \mathrm{~h}$. The fluorescence of the extract was measured with a Turner Designs fluorometer.

Bacteria and autotrophic plankton enumeration. Bacterial and autotrophic picoeukaryotes, Synechococcus and Prochlorococcus abundances were determined by flow cytometry (Gasol \& del Giorgio 2000). Samples of $1.2 \mathrm{ml}$ were fixed with $1 \%$ paraformaldehyde and $0.05 \%$ glutaraldehyde (final concentration), left in the dark at room temperature for $10 \mathrm{~min}$ and then stored frozen at $-70^{\circ} \mathrm{C}$. Later, samples were unfrozen and run through a FACS-calibur (Becton \& Dickinson) flow cytometer with a laser emitting at $488 \mathrm{~nm}$. To determine bacterial abundance, a subsample of $200 \mu \mathrm{l}$ was stained with Syto13 (Molecular Probes) at $1.6 \mu \mathrm{M}$ (diluted in DMS) and left to stain in the dark for $15 \mathrm{~min}$. Subsamples were run at low speed (ca. $12 \mu \mathrm{min}^{-1}$ ) and data were acquired in log mode until 10000 events had been processed. As an internal standard, $10 \mu \mathrm{l}$ of a $10^{6} \mathrm{ml}^{-1}$ solution of yellow-green $0.92 \mu \mathrm{m}$ Polyscience latex beads was added to subsamples. Bacteria were detected by their signature in a plot of side scatter (SSC) versus green fluorescence (FL1).

Subsamples of $600 \mu \mathrm{l}$ were run at high speed (ca. $60 \mu \mathrm{l} \mathrm{min}{ }^{-1}$ ) for the determination of autotrophic picoeukaryotes, Synechococcus and Prochlorococcus. As for bacteria, the data were acquired in log mode until 10000 events had been processed. A volume of $10 \mu \mathrm{l}$ of a $10^{5} \mathrm{ml}^{-1}$ concentration of beads was used as an internal standard. Synechococcus was detected by their signature in a plot of orange fluorescence (FL2) versus red fluorescence (FL3). Prochlorococcus had a lower FL3 signal and no FL2 signal. Autotrophic picoplankton had higher FL3 signals and no FL2 signal.

Autotrophic nanoflagellate (ANF) samples were fixed with $10 \%$ glutaraldehyde (final concentration $1 \%$ ). Twenty $\mathrm{ml}$ were filtered through $0.8 \mu \mathrm{m}$ black polycarbonate filters and stained with DAPI (5 $\mu \mathrm{g} \mathrm{l}^{-1}$ final concentration); the filters were kept at $-20^{\circ} \mathrm{C}$. ANFs were counted on a Nikon Labophot epifluorescence microscope at 1250× (Porter \& Feig 1980) and sized using a calibrated ocular micrometer in 3 size classes ( 4 to 8,8 to 16 and $>16 \mu \mathrm{m}$ ).

For the identification and enumeration of the rest of the phytoplankton cells (mainly diatoms, dinoflagellates and coccolithophorids), samples were fixed with 
formalin-hexamine solution ( $0.4 \%$ final concentration). Counts were made with the Utermöhl technique (Utermöhl 1958) using $50 \mathrm{~cm}^{3}$ settling chambers. One transect of the chamber was observed at $400 \times$ magnification to count the smaller $(<20 \mu \mathrm{m})$ and more frequent organisms. Additionally, 1 transect or half of the chamber was observed at $200 \times$ to count cells of intermediate size (generally between 20 and $50 \mu \mathrm{m}$ ) and the whole chamber was scanned at $200 \times$ to count the large forms. The observed organisms were classified to the lowest possible taxonomic level.

Biomass calculations. Bacterial biomass was estimated by flow cytometry following the methodology described in Gasol \& del Giorgio (2000), using a carbon conversion factor of $0.35 \mathrm{pg} \mathrm{C} \mu^{-3}$ (Bjørnsen 1986). Chl a values were converted to carbon using a factor of $30 \mu \mathrm{g}$ of carbon per $\mu \mathrm{g}$ of chl a (Strickland 1960) which corresponds to the values observed in the upper layers of the water column (average $=32.5, \mathrm{SE}=4.6, \mathrm{n}=6$ ) in the NW Mediterranean Sea (Delgado et al. 1992).

Literature cell volumes for March in the NW Mediterranean (Ribes et al. 1999) were used to calculate the biovolumes of Synechococcus and picoeukaryotes. A mean size of $0.7 \mu \mathrm{m}$ (Vaulot et al. 1990) was used for Prochlorococcus volume calculations. A mean carbon content
$0.357 \mathrm{pg} \mathrm{C} \mathrm{mm}^{-3}$ for Synechococcus was derived from Bjørnsen (1986), Kana \& Gilbert (1987) and Verity et al. (1992). A conversion factor of $\mathrm{pg} \mathrm{C}^{\mathrm{C}} \mathrm{cell}^{-1}=0.433 \times$ $\left(\mu \mathrm{m}^{3}\right)^{0.863}$ was used for picoeukaryotes (Verity et al. 1992). For Procholococcus, a conversion factor of $0.133 \mathrm{pg} \mathrm{C} \mathrm{\mu m}^{-3}$ was used (Simon \& Azam 1989).

Cell volume of ANFs was calculated from the mean size of each size class assuming ellipsoidal cell shape. The carbon conversion factor used in this case was the same as for picoeukaryotes.

Diatom, dinoflagellate and coccolithophorid biomass estimations were also done from size measurements. At least 20 individuals of the most abundant forms were recorded with a video camera (Hitachi KPC503) at 400x. Then, each organism was measured (length and width) using NIH-Image software and its volume calculated using a geometrical approximation of its form. Carbon content was estimated from the conversion factor pg C cell ${ }^{-1}=0.109 \times\left(\mu \mathrm{m}^{3}\right)^{0.991}$ (Montagnes et al. 1994).

\section{RESULTS}

Data from replicated containers were highly consistent with each other. Nutrient concentrations, chl $a$ and

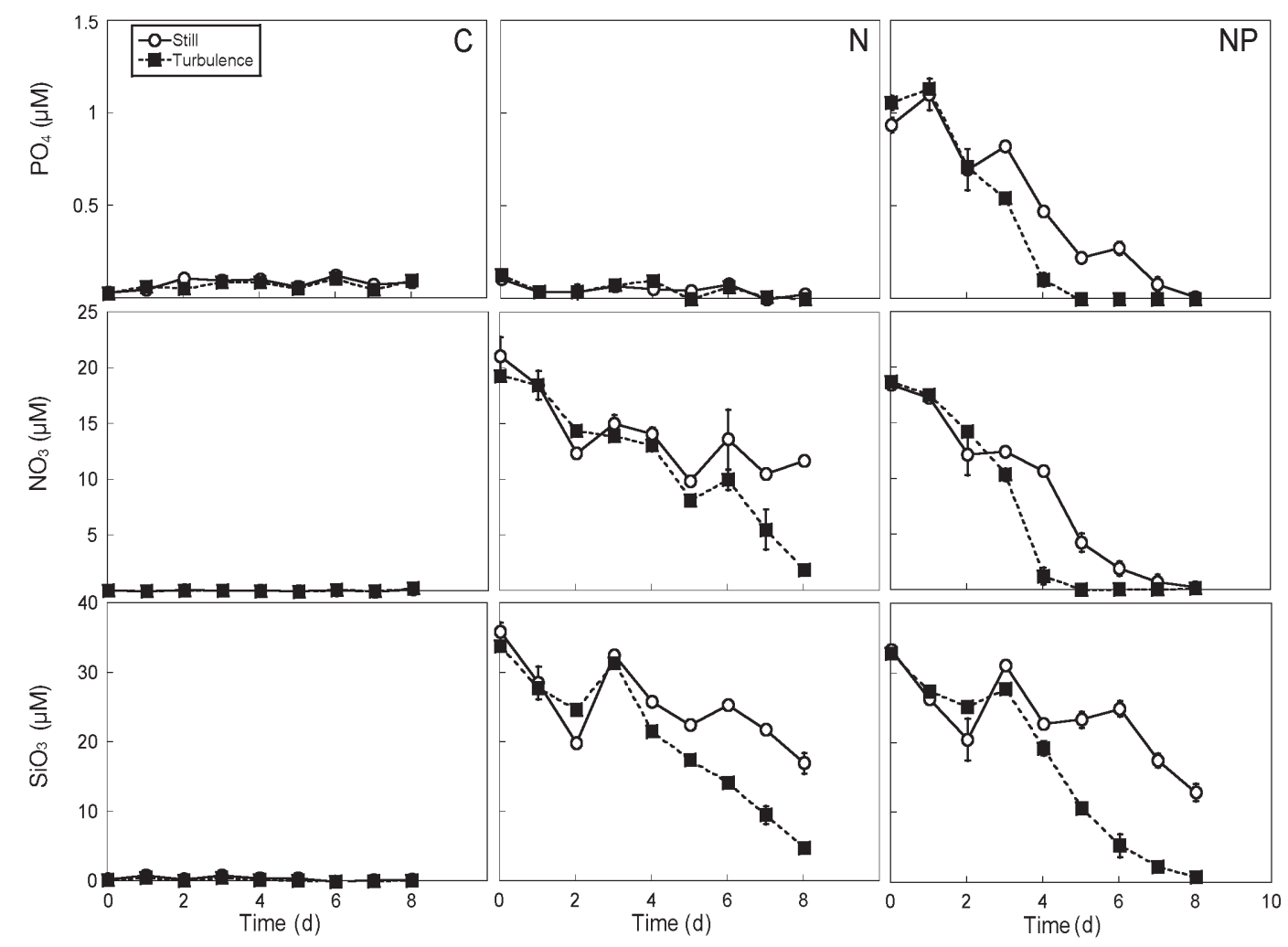

Fig. 1. Phosphate $\left(\mathrm{PO}_{4}\right)$, nitrate $\left(\mathrm{NO}_{3}\right)$ and silicate $\left(\mathrm{SiO}_{3}\right)$ concentrations $(\mu \mathrm{M})$ for the $\mathrm{C}$ (control), $\mathrm{N}$ (N-surplus) and NP (Redfield ratio) conditions (still and turbulent) during the experiment. Mean of 2 replicate microcosms per treatment \pm SE. No replicates for TN and TNP were available on Day 8 


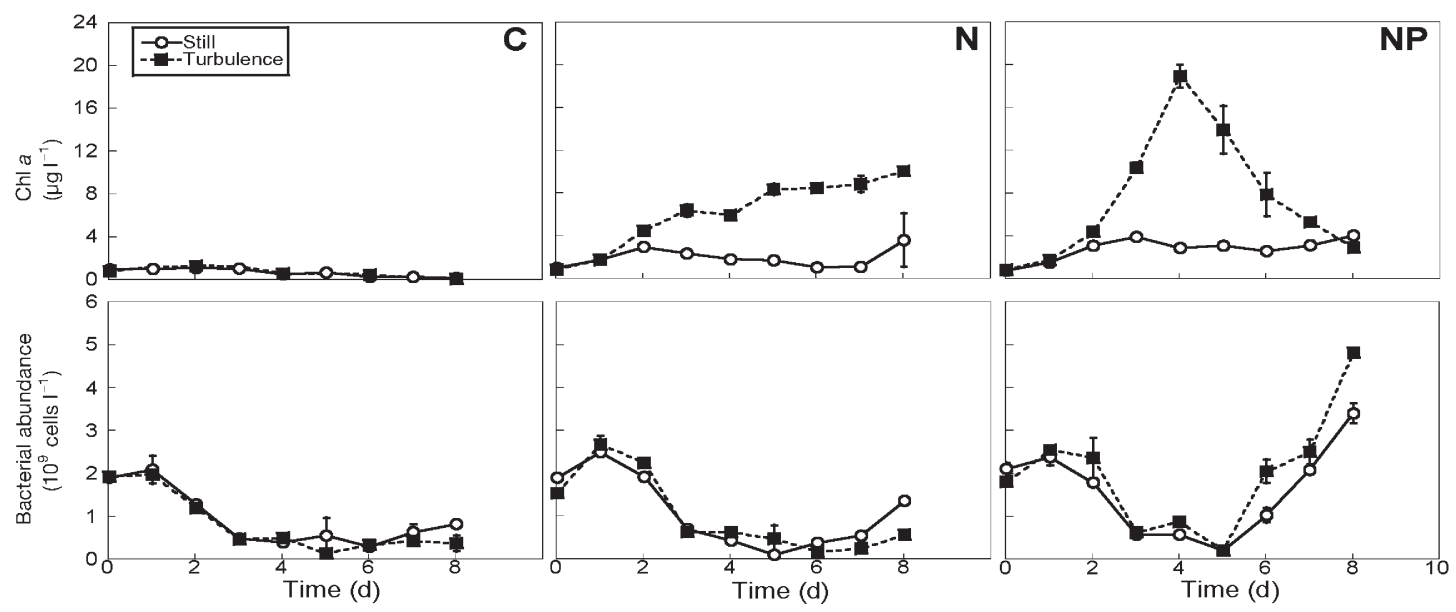

Fig. 2. Chl a concentration $\left(\mu \mathrm{g}^{-1}\right.$ ) and bacterial abundance (cells $\mathrm{l}^{-1}$ ) for the $\mathrm{C}$ (control), N (N-surplus) and NP (Redfield ratio) conditions (still and turbulent) over the course of the experiment. Mean of 2 replicate microcosms per treatment \pm SE. No replicates for TN and TNP were available on Day 8

bacteria showed no statistical differences among replicates for all treatments.

\section{Inorganic nutrients}

Variations of the inorganic nutrient concentrations during the experiment for the different treatments are shown in Fig. 1. In the controls, the initial concentrations of phosphate, nitrate and silicate were $0.03,0.08$ and $0.2 \mu \mathrm{M}$, respectively, and they remained at low concentrations during the experiment. In this treatment, no significant differences in nitrate and phosphate concentrations between still-control (SC) and turbulent-control (TC) containers were found. Silicate was slightly lower in $\mathrm{TC}(0.26 \mu \mathrm{M})$ than in $\mathrm{SC}$ $(0.48 \mu \mathrm{M})$.

In general, in the N and NP treatments, a decrease in phosphate, nitrate and silicate concentrations was observed throughout the experiment which was more evident with turbulence. Turbulence had a statistically significant effect on nutrient concentrations for the $\mathrm{N}$ and NP treatments, with the exception of phosphate in the $\mathrm{N}$ treatment where no difference was found. In the NP treatments, a depletion of phosphate and nitrate was observed in the turbulent containers from Day 5.

\section{Chl a}

The initial total chl a was around $1 \mu g \mathrm{l}^{-1}$ in all the containers (Fig. 2). In the controls, no significant difference in total chl a was observed between still and turbulent containers. In both, total chl a increased slightly during the first $2 \mathrm{~d}$ of the experiment and thereafter it started to decrease to around $0.20 \mu \mathrm{g}^{-1}$ by Day 8 .

In the N and NP treatments, significantly higher total chl a was observed in turbulent than in still containers from Day 2 ( $\mathrm{p}<0.001)$. In the turbulent $\mathrm{N}$ containers, total chl $a$ increased until the end of the experiment (up to $10.2 \mathrm{\mu g} \mathrm{l}^{-1}$ of chl a), while in turbulent NP containers total chl a peaked at Day 4 with a concentration of $19.0 \pm 1.1 \mathrm{\mu g} \mathrm{l}^{-1}$. In the still containers, total $\mathrm{chl} a$ increased during the first 2 to $3 \mathrm{~d}$, reaching a maximum of $3.7 \pm 2.5$ and $4.2 \pm 0.2 \mu \mathrm{g} \mathrm{l}^{-1}$ in the $\mathrm{N}$ and NP treatments, respectively.

The ratio of the $>10 \mu \mathrm{m}$ chl a fraction with respect to total chl a showed no significant differences owing to turbulence in $\mathrm{C}$ containers (Fig. 3). However, in the $\mathrm{N}$ and NP containers, significant higher values of $>10 \mu \mathrm{m}$ chl a:total chl a ratio were found in the turbulent treatments after Day 2 or 3 ( $p<0.001)$.

\section{Bacterial abundance}

No significant differences in bacterial abundance were observed between still and turbulent containers in all the treatments (Fig. 2). However, in the NP containers, the tendency in the last days of the experiments (from Day 5) was a higher bacterial abundance under turbulence. Initial bacterial numbers in all the

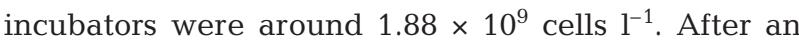
increase at Day 1 , bacterial abundance decreased down to $5.12 \times 10^{8}$ cells $\mathrm{l}^{-1}$ at Day 5 or 6 . Thereafter, the values increased again until the end of the experiment. The highest increase was in the NP treatments. 


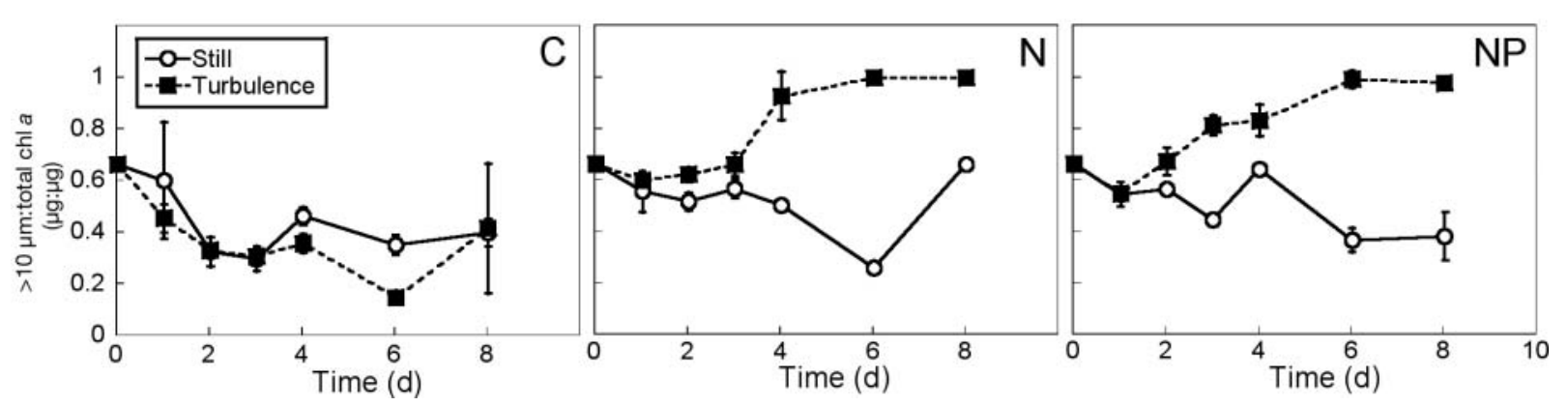

Fig. 3. Ratio of the $>10 \mu \mathrm{m} \mathrm{chl} \mathrm{a} \mathrm{fraction} \mathrm{with} \mathrm{respect} \mathrm{to} \mathrm{total} \mathrm{chl} \mathrm{a} \mathrm{for} \mathrm{the} \mathrm{C} \mathrm{(control),} \mathrm{N} \mathrm{(N-surplus)} \mathrm{and} \mathrm{NP} \mathrm{(Redfield} \mathrm{ratio)} \mathrm{con-}$ ditions (still and turbulent) during the experiment. Mean of 2 replicate microcosms per treatment \pm SE. No replicates for TN and TNP were available on Day 8

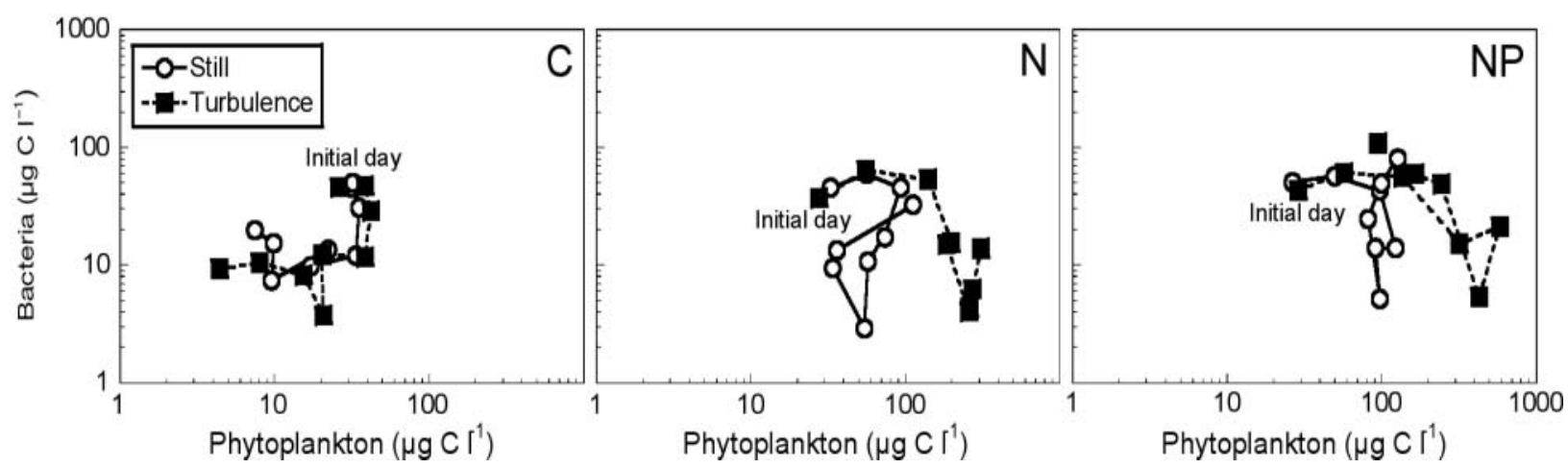

Fig. 4. Relationship between bacterial and phytoplankton biomass (as derived from chl a) for the C (control), $\mathrm{N}$ ( $\mathrm{N}$-surplus) and NP (Redfield ratio) conditions (still and turbulence) for the $9 \mathrm{~d}$ sampled. Initial day = initial day (Day 0 ) of the experiment
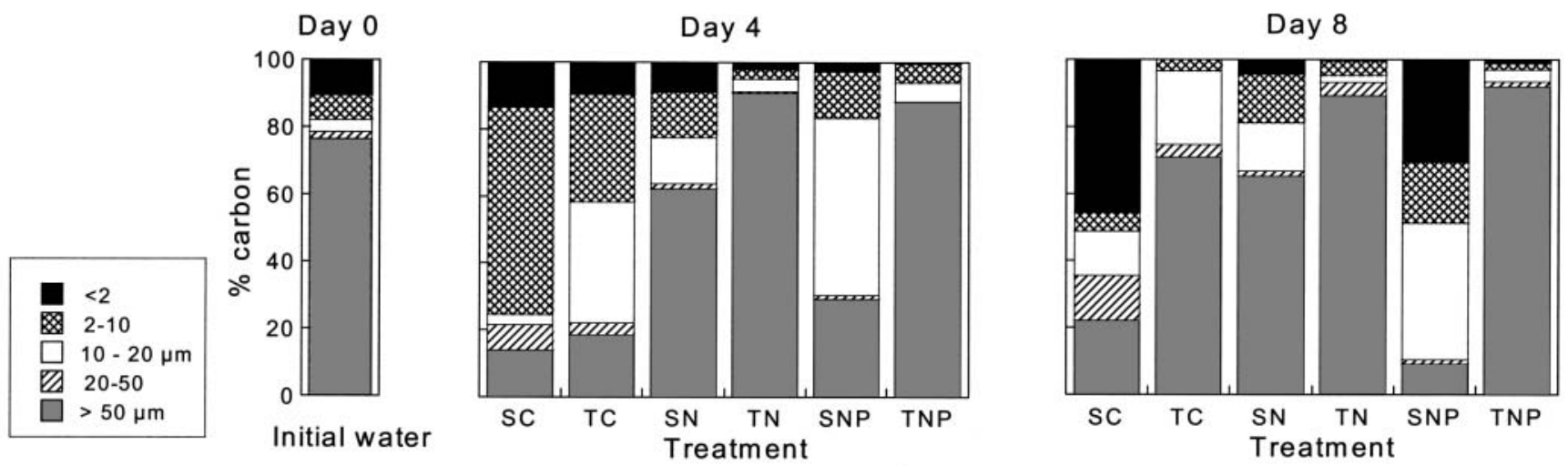

Fig. 5. Phytoplankton size distribution for the initial water (Day 0), and for the C (control), N (N-surplus) and NP (Redfield ratio) conditions (still and turbulent) on Days 4 and 8. Mean of 2 replicate microcosms per treatment. The associated errors between replicates are given in Table 3 where absolute values are shown. No replicates for TN and TNP were available on Day 8

The relationship between bacteria and phytoplankton biomass (as derived from chl a) for the $\mathrm{C}$, $\mathrm{N}$ and NP treatments during the experiment is presented in Fig. 4. In $\mathrm{C}$, the evolution of the phytoplankton and bacterial biomass during the experiment was similar in both the still and the turbulent containers. However, in $\mathrm{N}$ and NP, from approximately the same bacterial biomass evolution, we found higher values of phytoplankton biomass under turbulence (from Day 2 and until the end of the experiment in the $\mathrm{N}$ treatments and between Days 3 and 6 in the NP ones). 
Table 2. Chlorophyll a concentrations $\left(\mu \mathrm{g} \mathrm{l}^{-1}\right.$ ) and bacterial abundance (cells $\mathrm{l}^{-1}$ ) (mean of 2 replicate microcosms $\pm \mathrm{SE}$ ) at the end of the experiment (Day 8) in the water column and in the water column plus the resuspended biomass for the still (S) and turbulent (T) containers of the C (control), N (N-Surpluls) and NP (Redfield ratio) conditions. No replicates for TN and TNP were available on Day 8

\begin{tabular}{|c|c|c|c|c|}
\hline \multirow{2}{*}{ Treatment } & \multicolumn{2}{|c|}{$\longrightarrow$ Chl a } & & \multirow{2}{*}{$\begin{array}{l}\text { Bacteria } \\
\text { Water column + resuspended }\end{array}$} \\
\hline & Water column & Water column + resuspended & Water column & \\
\hline $\mathrm{SC}$ & $0.25 \pm 0.05$ & $1.13 \pm 0.09$ & $8.41 \pm 0.34\left(\times 10^{8}\right)$ & $8.50 \pm 1.09\left(\times 10^{8}\right)$ \\
\hline TC & $0.15 \pm 0.02$ & $1.94 \pm 0.05$ & $3.96 \pm 1.88\left(\times 10^{8}\right)$ & $4.58 \pm 2.41\left(\times 10^{8}\right)$ \\
\hline SN & $3.68 \pm 2.50$ & $6.73 \pm 0.19$ & $1.38 \pm 0.10\left(\times 10^{9}\right)$ & $1.81 \pm 0.37\left(\times 10^{9}\right)$ \\
\hline TN & 10.15 & 23.38 & $0.58\left(\times 10^{9}\right)$ & $1.00\left(\times 10^{9}\right)$ \\
\hline SNP & $4.17 \pm 0.21$ & $13.47 \pm 5.56$ & $3.43 \pm 0.23\left(\times 10^{9}\right)$ & $6.37 \pm 0.17\left(\times 10^{9}\right)$ \\
\hline TNP & 3.01 & 17.64 & $4.84\left(\times 10^{9}\right)$ & $7.24\left(\times 10^{9}\right)$ \\
\hline
\end{tabular}

\section{Chl $a$ and bacteria sedimentation}

Table 2 shows the chl a concentration and bacterial abundance of the water column and of the water column plus the resuspended biomass at the end of the experiment (Day 8). Sedimented phytoplankton was higher in turbulent than in still treatments, while sedimented bacteria were, in general, similar in both treatments.

\section{Phytoplankton size distribution and composition}

In general, the highest percentage of large cells (>50 $\mu \mathrm{m})$ was observed in the turbulent containers, especially when nutrients were added (Fig. 5). The fraction $>50 \mu \mathrm{m}$ represented more than $85 \%$ of the autotrophic carbon in the TN and TNP containers and around $70 \%$ in the TC containers at Day 8, although their contribution in absolute values (in terms of carbon) was very different (Table 3 ). This fraction was between 55 and 173 and between 131 and 178 times higher in TN and TNP than in TC containers, respectively. In all the treatments, the most abundant taxa in these fractions were species of 2 chain-forming diatom genera: Chaetoceros and Pseudo-nitzschia.

Among the 3 still containers, the highest percentages of autotrophic carbon $<20 \mu \mathrm{m}$ were found in the $\mathrm{C}$ and NP treatments. On Day 8, the fraction $<2 \mu \mathrm{m}$ was remarkably high (more than $30 \%$ of the total autotrophic carbon) in these 2 treatments. Prochlorococcus was not observed in any of the treatments while Synechococcus decreased to undetectable concentrations by Day 4

Independent of the percentage of each size fraction present in the different containers, almost $100 \%$ of the cells $>50 \mu \mathrm{m}$ corresponded to diatoms, while dinoflagellates were more frequent in the 10 to $50 \mu \mathrm{m}$ size fraction (data not shown). The ratio of diatoms to total phytoplankton ( $\mu \mathrm{g} \mathrm{C}: \mu \mathrm{g} \mathrm{C}$ ) was higher in turbulent conditions, especially when nutrients were added (Fig. 6). On Day 4, when nutrients were still available

Table 3. Carbon content $\left(\mu \mathrm{g}^{-1}\right)$ in the different size classes (mean of 2 replicate microcosms $\pm \mathrm{SE}$ ) of the autotrophic biomass on Days 0, 4 and 8 for the still (S) and turbulent (T) containers of the C (control), N (N-surplus) and NP (Redfield ratio) conditions. No replicates for TN and TNP were available on Day 8

\begin{tabular}{|c|c|c|c|c|c|c|c|}
\hline \multirow{2}{*}{$\begin{array}{l}\text { Size fraction } \\
(\mu \mathrm{m})\end{array}$} & \multirow{2}{*}{$\begin{array}{c}\text { Day } 0 \\
\text { Initial water }\end{array}$} & \multicolumn{6}{|c|}{ Day 4} \\
\hline & & $\mathrm{SC}$ & $\mathrm{TC}$ & SN & $\mathrm{TN}$ & SNP & TNP \\
\hline$<2$ & 5.2 & $2.45 \pm 0.04$ & $2.46 \pm 0.09$ & $5.88 \pm 0.59$ & $5.25 \pm 0.42$ & $4.93 \pm 0.17$ & $3.19 \pm 0.07$ \\
\hline $2-10$ & $3.91 \pm 1.47$ & $11.88 \pm 3.08$ & $8.38 \pm 0.67$ & $9.71 \pm 3.40$ & $7.73 \pm 1.29$ & $25.09 \pm 11.13$ & $50.05 \pm 9.91$ \\
\hline $10-20$ & $1.71 \pm 0.23$ & $0.53 \pm 0.15$ & $18.13 \pm 17.52$ & $8.53 \pm 6.43$ & $11.15 \pm 8.65$ & $104.17 \pm 34.53$ & $50.64 \pm 47.39$ \\
\hline $20-50$ & $1.24 \pm 0.96$ & $1.49 \pm 0.59$ & $0.84 \pm 0.07$ & $1.08 \pm 0.19$ & $1.51 \pm 0.34$ & $1.77 \pm 0.48$ & $1.80 \pm 0.48$ \\
\hline$>50$ & $38.95 \pm 6.25$ & $2.60 \pm 0.21$ & $4.43 \pm 0.42$ & $44.08 \pm 13.25$ & $243.10 \pm 28.15$ & $55.56 \pm 0.09$ & $787.15 \pm 69.15$ \\
\hline$<2$ & & $2.00 \pm 0.49$ & 0 & $2.92 \pm 0.32$ & 1.13 & $34.95 \pm 4.54$ & 3.31 \\
\hline $2-10$ & & $0.62 \pm 0.62$ & $0.10 \pm 0.01$ & $9.24 \pm 0.20$ & 17.97 & $20.92 \pm 3.47$ & 5.86 \\
\hline $10-20$ & & $0.39 \pm 0.13$ & $0.74 \pm 0.44$ & $9.14 \pm 0.37$ & 8.58 & $47.23 \pm 8.96$ & 10.42 \\
\hline $20-50$ & & $1.43 \pm 1.40$ & $0.11 \pm 0.01$ & $1.12 \pm 0.21$ & 16.33 & $1.40 \pm 0.21$ & 4.33 \\
\hline$>50$ & & $2.17 \pm 2.04$ & $2.10 \pm 0.23$ & $82.66 \pm 65.87$ & 363.00 & $12.77 \pm 11.09$ & 275.27 \\
\hline
\end{tabular}



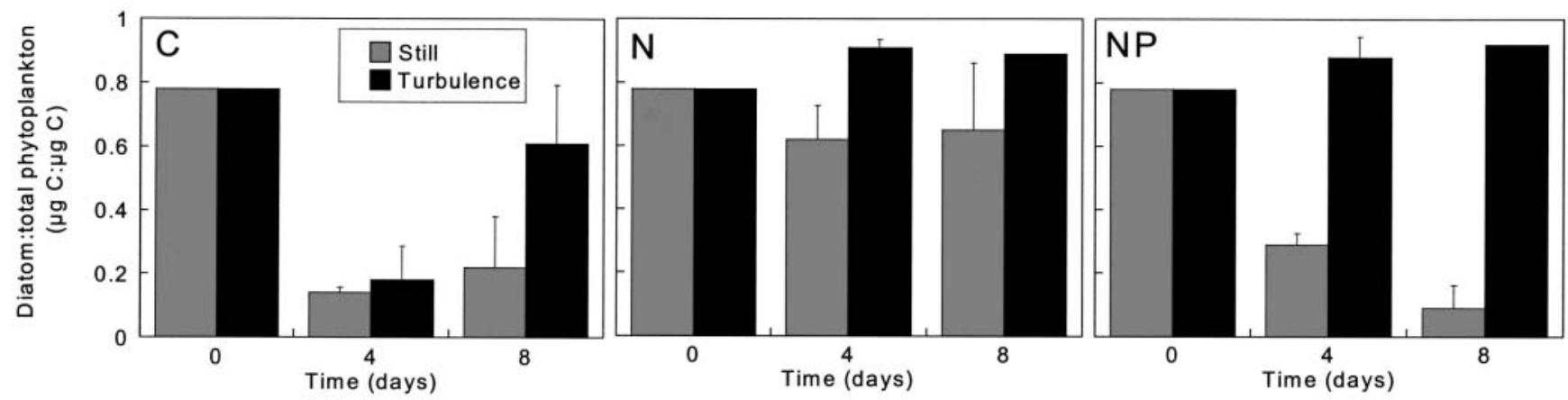

Fig. 6. Diatom:total phytoplankton ratio for the $\mathrm{C}$ (control), N (N-surplus) and NP (Redfield ratio) conditions (still and turbulent) on Days 0, 4 and 8. Mean of 2 replicate microcosms per treatment \pm SE. No replicates for TN and TNP were available on Day 8

in both treatments, this ratio was 3 times higher in the TNP than in the still Redfield ratio (SNP) containers and around 1.5 times higher in the TN than in the still $\mathrm{N}$-surplus (SN) containers. Although practically no differences were observed in the diatom:total phytoplankton ratio between the turbulence containers of the N and NP treatments (around 90\% in both), in the still containers higher percentages of the ratio were found in the N (62 to $65 \%$ ) than in the NP treatments (9 to $29 \%$ ). Without nutrient additions (TC and SC treatments), diatoms had a low contribution (see >50 $\mu \mathrm{m}$ size fraction in Table 3). But even so, turbulence increased the relative importance of diatoms in relation to total biomass (2.8 times higher on Day 8).

\section{DISCUSSION}

The effect of turbulence on the dynamics of plankton was different depending on the nutrient conditions. No clear effect was found at very low nutrient concentrations (control containers). In these conditions, the hypothesised increase in nutrient flux to large cells due to turbulence was not enough to increase significantly the growth of osmotrophic organisms of any size, and therefore not enough to change the relative importance of bacteria to phytoplankton biomass. However, when nutrients were added ( $\mathrm{N}$ and NP containers), the effect of turbulence was noticeable. Petersen et al. (1998) who examined coastal phytoplankton responses to different levels of turbulence in mesocosms, also found the effect of turbulence to be dependent on nutrient conditions. They observed no differences in the chl a concentration between turbulence treatments before nutrient addition. However, after a nutrient pulse, they did observe differences in chl a concentration. In our studies, although some trends were coincident for $\mathrm{N}$ (P deficient enrichment) and NP (N:P balanced enrichment) treatments, the timing and the magnitude of the response to turbulence were slightly different.

In the TNP containers, phytoplankton grew rapidly until Day 4 and then decreased abruptly until the end of the experiment. However, in $\mathrm{TN}$, a continuous growth of phytoplankton was observed (Fig. 2). These differences in phytoplankton growth could be explained by the dynamics of nutrients. In TNP, nitrate and phosphorus were initially added in the Redfield ratio and proportionally consumed by the phytoplankton community until Day 4 when they were almost depleted. After this day, neither nitrate nor phosphate were available and thus phytoplankton biomass started to decrease. However, in TN, the initial addition of a surplus of nitrate enabled the growth of phytoplankton at a constant rate until the end of the experiment. Although phosphate was present at very low concentrations, it was probably quickly recycled (see Maar et al. 2002, this issue). Thus, the effects of turbulence on the growth of the phytoplankton community could change depending on the proportion and the concentration of nutrients in the water. The higher autotrophic biomass observed in the water column of the turbulent containers was due to a higher phytoplankton growth since sedimented chl a measured on Day 8 was also higher in these containers (Table 2).

Bacterial dynamics were practically the same in turbulent and nonturbulent containers. Bacteria increased initially (Day 1) but then decreased until Day 5 or 6. Afterwards, another increase of bacteria was observed which was most evident in the NP containers. This initial increase in bacteria followed by a decrease has been observed in other microcosm experiments (Berdalet et al. 1996). The growth of bacteria observed from Day 5 could be explained by the presence of more degradable organic carbon (mostly produced by phytoplankton excretion) and the presence of inorganic nutrients, which in the TNP containers were probably recycled. 


\section{Bacteria-phytoplankton relationship}

The relationship between bacteria and phytoplankton biomass (as derived from chl a, Fig. 4) showed that there were no differences over time between turbulent and still containers when the water was not enriched. However, in the N and NP treatments, lower values of bacteria:phytoplankton were observed with turbulence from Day 3 until the end of the experiment. Thus, turbulence increased the relative importance of phytoplankton to bacteria, as we expected, but only in the microcosms in which nutrients were added. These results are in contrast with those in Peters et al. (1998) who found high bacterial abundance under turbulence. They concluded that the grazing of microflagellates shifted from smaller (bacteria) to larger organisms (autotrophic pico- and nanoplankton). In our experiment, although non-significant differences were observed in bacterial abundance between still and turbulent containers in all the treatments, a higher bacterial abundance was observed under turbulence during the last days of the experiment in NP containers (Fig. 2). This difference was not due to a higher activity of bacteria under turbulence because the specific leucine uptake rates were higher in the still than in the turbulent containers (data not shown). This finding could indicate that top-down interactions dominated bacterial population dynamics during the last days.

Peters et al. (2002) found that turbulence increased the heterotrophy in the system, and again argued in favour of a biomass shift to larger heterotrophic components through changes in grazing interactions. However, in terms of nutrient conditions, there are some fundamental differences between those studies and the one described in this paper. We added a relatively high single pulse of nutrients at the beginning of the experiment while no nutrients or low daily nutrient pulses were added in Peters et al. (1998) and (2002), respectively. In this study, the addition of nutrients allowed turbulence to favour large phytoplankton species, while in our previous studies phytoplankton was dominated by pico- and nanoautotrophs.

\section{Phytoplankton size distribution and composition}

As expected, the average size of phytoplankton cells was higher under turbulence. This result agrees with theoretical approaches (Lazier \& Mann 1989, KarpBoss et al. 1996) which concluded that the beneficial effect of turbulence on the nutrient flux to the cells increases with cell size. In our experiments, this differential benefit among sizes was clear, especially in NP treatments. Diatoms were the main component of the highest size fraction observed $(>50 \mu \mathrm{m})$ and, within this group, cells from 2 genera (Chaetoceros and Pseudo-nitzschia) were the most abundant. These species form chains and could benefit from turbulence and nutrient-rich situations by increasing their advective transport of nutrients or increasing their total length (Pahlow et al. 1997). In turbulence treatments, the chain length of Chaetoceros spp. and Pseudo-nitzschia spp. was larger than in still treatments (data not shown). The dominance of diatoms in the turbulent conditions agrees with existing theory (Margalef 1978) and with results from previous experiments (Estrada et al. 1987).

It is also remarkable to note the different responses in still waters depending on nutrient enrichment. We found a much lower diatom contribution to the total phytoplankton biomass in the NP (nutrient balance) than in the $\mathrm{N}$-surplus (P-deficient) containers (Fig. 6). These results are in contrast to the findings of Egge (1998), who found that diatoms (in terms of abundance) did not dominate when $\mathrm{P}$ was deficient. In our experiment, when the contribution of diatoms is expressed in terms of abundance, the differences between the 2 still enrichment treatments ( $\mathrm{N}$ and NP) were smaller (5.5 to 7.7 and 0.4 to $6.9 \%$, respectively), but the higher percentages in the $\mathrm{N}$ treatment persisted. In contrast, under turbulent conditions, we found a higher diatom:total phytoplankton ratio in the NP than in the N treatments (40 vs $11 \%$ ) at Day 4 . The experiments in Egge (1998) were performed in mesocosms in which airlifts were used, therefore producing unquantified turbulence. Thus, Egge's results could be more similar to our turbulence treatment. The species-specific response to nutrient addition should be further studied under different hydrodynamic conditions in order to better understand the competition interactions for nutrient resources among different life forms.

Several authors have pointed out both bottom-up and top-down effects of turbulence on marine planktonic communities. Bottom-up effects may favour nutrient flux to big cells (Karp-Boss et al. 1996) and top-down effects may increase encounter probability between predators and prey (Rothschild \& Osborn 1988, Marrasé et al. 1990, Sundby \& Fossum 1990), or influence predator behaviour (Costello et al. 1990, Saiz \& Kiørboe 1995, Peters et al. 1998). The combination of these effects rarely compensate each other and turbulence drives the system, at least temporarily, to a different state in relation to still conditions. As shown here, the magnitude and duration of the changes induced by turbulence depend on initial nutrient conditions. Given that turbulence modifies the response of plankton to nutrients, it can be concluded that parameterisations of biological processes (e.g. nutrient uptake and grazing rates) to be used in predictive models should be derived from studies in which the hydrodynamic conditions are considered. 
Acknowledgements. We are grateful to captain Elías Barrenechea and the staff at the Masnou harbour for letting us use their boat and helping us with sampling. We thank Mercedes Castaño and Cristina Roldán for laboratory assistance, Roser Ventosa for nutrient analysis and Oscar Guadayol for calculation of turbulence intensities in the NW Mediterranean. Marta Estrada provided helpful comments on the manuscript. The comments and suggestions by 3 anonymous reviewers greatly improved previous versions of the manuscript. Aisling Metcalfe was of great help editing the English. This work was supported by the European projects NTAP (EVK3-CT-2000-00022) and BIOHAB (EVK3-CT99-00015), and the Spanish CICYT project (MAR 98-0854). This is ELOISE Contribution No. 277/40.

\section{LITERATURE CITED}

Berdalet E (1992) Effects of turbulence on the marine dinoflagellate Gymnodinium nelsonii. J Phycol 28:267-272

Berdalet E, Marrasé C, Estrada M, Arin L, MacLean ML (1996) Microbial community responses to nitrogen- and phosphorus- deficient nutrient imputs: microplankton dynamics and biochemical characterization. J Plankton Res 18(9):1627-1641

Bjørnsen PK (1986) Automatic determination of bacterioplankton biomass by image analysis. Appl Environ Microbiol 51:1199-1204

Canelli E, Fuhs GW (1976) Effect of the sinking rate of two diatoms (Thalassiosira spp.) on the uptake from low concentration of phosphate. J Phycol 12:93-99

Costello JH, Strickler JR, Marrasé C, Trager G, Zeller R, Freise AJ (1990) Grazing in a turbulent environment: behavioral response of a calanoid copepod, Centropages hamatus. Proc Natl Acad Sci USA 87:1648-1652

Delgado M, Latasa M, Estrada M (1992) Variability in the size-fractionated distribution of the phytoplankton across the Catalan front of the north-west Mediterranean. J Plankton Res 14(5):753-771

Egge JK (1998) Are diatoms poor competitors at low phosphate concentration? J Mar Syst 16:191-198

Estrada M, Berdalet E (1998) Effects of turbulence on phytoplankton. In: Anderson DM, Cembella AD, Hallegraeff GM (eds) Physiological ecology of harmful algal blooms. NATO ASI Series, Vol G41. Springer-Verlag, Berlin, p 601-618

Estrada M, Alcaraz M, Marrasé C (1987) Effects of turbulence on the composition of phytoplankton assemblages in marine microcosms. Mar Ecol Prog Ser 36:267-281

Estrada M, Marrasé C, Alcaraz M (1988) Phytoplankton response to intermittent stirring and nutrient addition in marine microcosms. Mar Ecol Prog Ser 48:225-234

Gasol JM, del Giorgio PA (2000) Using flow cytometry for counting natural planktonic bacteria and understanding the structure of planktonic bacterial communities. Sci Mar 64(2):197-224

Grasshoff K, Ehrhardt M, Kremling K (1983) Methods of seawater analysis, 2nd edn. Verlag Chemie, Weinheim

Guillard RRL (1975) Culture of phytoplankton for feeding marine invertebrates. In: Smith W, Chanley MH (eds) Culture of marine invertebrates. Plenum Publishing, New York, p 26-60

Kana T, Gilbert PM (1987) Effect on irradiance up to $2000 \mu \mathrm{E}$ $\mathrm{m}^{-2} \mathrm{~s}^{-2}$ on marine Synechococcus WH 7803-I. Growth: pigmentation and cell composition. Deep-Sea Res 34:479-516

Karp-Boss L, Jumars PA (1998) Motion of diatom chains in steady shear flow. Limnol Oceanogr 43(8):1767-1773
Karp-Boss L, Boss E, Jumars PA (1996) Nutrient fluxes to planktonic osmotrophs in the presence of fluid motion. Oceanogr Mar Biol Annu Rev 34:71-107

Karp-Boss L, Boss E, Jumars PA (2000) Motion of dinoflagellates in a simple shear flow. Limnol Oceanogr 45(7): 1594-1602

Kiørboe T, Saiz E (1995) Planktivorous feeding in calm and turbulent environments, with emphasis on copepods. Mar Ecol Prog Ser 122:135-145

Köhler J (1997) Measurement of in situ growth rates of phytoplankton under conditions of simulated turbulence. J Plankton Res 19(7):849-862

Lazier JRN, Mann KH (1989) Turbulence and the diffusive layers around small organisms. Deep-Sea Res 36: 1721-1733

Maar M, Arin L, Simó R, Sala MM, Peters F, Marrasé C (2002) Combined effects of nutrients and small-scale turbulence in a microcosms experiment. II. Dynamics of organic matter and phosphorus. Aquat Microb Ecol 29:63-72

MacKenzie BR, Leggett WC (1993) Wind-based models for estimating the dissipation rates of turbulent energy in aquatic environments: empirical comparisons. Mar Ecol Prog Ser 94:207-216

Margalef R (1978) Life-forms of phytoplankton as survival alternatives in an unstable environment. Oceanol Acta 1: 493-509

Marrasé C, Costello JH, Granata T, Strickler JR (1990) Grazing in a turbulent environment: energy dissipation, encounter rates, and efficacy of feeding currents in Centrophages hamatus. Proc Natl Acad Sci USA 87: 1653-1657

Montagnes DJ, Berges SJA, Harrison PJ, Taylor FJR (1994) Estimating carbon, nitrogen, protein and chl a from volume in marine phytoplankton. Limnol Oceanogr 39: $1044-1060$

Oviatt CA (1981) Effects of different mixing schedules on phytoplankton, zooplankton and nutrients on marine microcosms. Mar Ecol Prog Ser 4(1):57-67

Pahlow M, Riebesell U, Wolf-Gladrow DA (1997) Impact of cell shape and chain formation on nutrient acquisition by marine diatoms. Limnol Oceanogr 42(2):1660-1672

Pasciak WJ, Gavis J (1975) Transport limited nutrient uptake rates in Ditylum brightwellii. Limnol Oceanogr 20: 604-617

Peters F, Gross T (1994) Increased grazing rates of microplankton in response to small-scale turbulence. Mar Ecol Prog Ser 115:299-307

Peters F, Marrasé C, Gasol JM, Sala MM, Arin L (1998) Effects of turbulence on bacterial growth mediates through food web interactions. Mar Ecol Prog Ser 172:293-303

Peters F, Marrasé C, Havskum H, Rassoulzadegan F, Dolan J, Alcaraz M, Gasol JM (2002) Turbulence and the microbial food web: effects on bacterial losses to predation and on community structure. J Plankton Res 24:321-331

Petersen JE, Sanford LP, Kemp WM (1998) Coastal plankton responses to turbulence mixing in experimental ecosystem. Mar Ecol Prog Ser 171:23-41

Porter KG, Feig YS (1980) The use of DAPI for identifying and counting aquatic microflora. Limnol Oceanogr 25:943-948

Ribes M, Coma R, Gili JM (1999) Seasonal variation of particulate organic carbon, dissolved organic carbon and the contribution of microbial communities to the live particulate organic carbon in a shallow near-bottom ecosystem at the Northwestern Mediterranean Sea. J Plankton Res 21(6):1077-1100

Rothschild BJ, Osborn TR (1988) Small-scale turbulence and plankton contact rates. J Plankton Res 10:465-474 
Saiz E, Kiørboe T (1995) Predatory and suspension feeding on the copepod Acartia tonsa in turbulent environments. Mar Ecol Prog Ser 122:147-158

Savidge G (1981) Studies of the effects of small-scale turbulence on phytoplankton. J Mar Biol Assoc UK 61:477-488

Simon M, Azam F (1989) Protein content and protein synthesis rates of planktonic marine bacteria. Mar Ecol Prog Ser 51:201-213

Strickland JDH (1960) Measuring the production of marine phytoplankton. Bull Fish Res Board Can 122:1-172

Sundby S, Fossum P (1990) Feeding conditions of ArcoNorwegian cod larvae compared with the RothschildOsborn theory on small-scale turbulence and plankton contact rates. J Plankton Res 12:1153-1162

Svensen C, Egge JK, Stiansen JE (2001) Can silicate and turbulence regulate the vertical flux of biogenic matter? A mesocosms study. Mar Ecol Prog Ser 217:67-80

Thomas WH, Gibson CH (1990) Effects of small-scale turbulence on microalgae. J Appl Phycol 2:71-77

Editorial responsibility: Frede Thingstad,

Bergen, Norway
Thomas WH, Vernet M, Gibson CH (1995) Effects of smallscale turbulence on photosynthesis, pigmentation, cell division, and cell size in the marine dinoflagellate Gonyaulax polyedra (Dinophyceae). J Phycol 31:50-59

Utermöhl H (1958) Zur Vervollkommung der quantitativen Phytoplankton-Methodik. Mitt Int Ver Theor Angew Limnol 9:1-38

Vaulot D, Partensky F, Neveus J, Mantoura RFC, Llewellyn C (1990) Winter presence of prochlorophytes in surface waters of the northwestern Mediterranean Sea. Limnol Oceanogr 35:1156-1164

Verity PG, Robertson CY, Tronzo CR, Andrews MG, Nelson JR, Sieracki ME (1992) Relationships between cell volume and the carbon and nitrogen content of marine photosynthetic nanoplankton. Limnol Oceanogr 37: $1434-1446$

Yentsch CS, Menzel DW (1963) A method for the determination of phytoplankton chlorophyll and phaeophytin by fluorescence. Deep-Sea Res 10:221-231

Submitted: July 28, 2001; Accepted: May 5, 2002

Proofs received from author(s): August 5, 2002 